\title{
Development and evaluation of accessories to improve the posture of veterinary surgeons in surgical procedures conducted in the field
}

\author{
[Desenvolvimento e avaliação de acessórios para melhorar a postura de cirurgiões \\ veterinários em procedimentos cirúrgicos realizados a campo] \\ V.A.S. Vulcani ${ }^{1}$, L.A.F. Silva ${ }^{1}$, R.E. Rabelo ${ }^{1}$, O. C. Silva ${ }^{1}$, L.A. Mendes ${ }^{2}$, \\ S.L.R. Freitas ${ }^{3}$, A.S. Rabbers ${ }^{3}$, B.M. Assis $^{3}$ \\ ${ }^{1}$ Escola de Veterinária e Zootecnia - Universidade Federal de Goiás - Goiânia, GO \\ ${ }^{2}$ Aluno de graduação - Iniciação/CNPq - Universidade Federal de Goiás - Goiânia, GO \\ ${ }^{3}$ Aluno de pós-graduação - Universidade Federal de Goiás - Goiânia, GO
}

\begin{abstract}
The study was conducted based on the information collected on rural properties in the state of Goiás, during practical classes of Surgical Clinic in Large Animals at the Veterinary Hospital of the Escola de Veterinária e Zootecnia of the Universidade Federal de Goiás and during the implementation of outreach projects developed by the institution. An acropostite-phimosis surgical procedure in the bulls in the field was selected, lasting over 30 minutes and requiring movements, posture and strength on the part of the surgeon. Devices were proposed and developed to provide improved comfort and safety to surgeons. The first device was a stool to be used by the professional during the execution of the surgical intervention. The use enabled the surgeon to sit down and rest their feet on the ground, reducing knee bending and distributing the support forces in various muscle groups. For the movement restriction of the surgeon, another accessory was developed to support the foreskin of the animal. Made of wood, this other device serves as a support for keeping the foreskin away from the ground and close to the surgeon. Its length, width and thickness established a good relation with the stool height, providing minimal discomfort to the professional. The third device was designed to assist in the immobilization of the animal and increase safety for the patient and surgical team. A fourth accessory was designed to protect the scapular region and avoid the occurrence of injuries in the radial nerve, myopathies and traumas during the rollover or prolonged stay of the animal in lateral decubitus. The choice of the shape, dimensions and softness of the device was mainly based on the weight of the animal. Such devices have proven to be effective, reducing the time of surgery, making cervical and lumbar movement easier, in addition to providing better support to the surgeon, reducing risks of musculoskeletal diseases.
\end{abstract}

Keywords: bovine, surgery, diseases, postoperative

\section{RESUMO}

O estudo foi realizado com base nas informações coletadas em propriedades rurais do estado de Goiás, durante aulas práticas de Clínica Cirúrgica de Grandes Animais no Hospital Veterinário da Escola de Veterinária e Zootecnia da Universidade Federal de Goiás e durante a execução de projetos de extensão desenvolvidos pela instituição. Foi selecionado um procedimento cirúrgico de acropostite-fimose em touros a campo, com duração acima de 30 minutos e com exigência de movimentos, postura e força por parte do cirurgião. Foram propostos e desenvolvidos dispositivos para proporcionar melhor conforto e segurança aos cirurgiões. O primeiro consistiu de um assento para ser usado pelo profissional durante a execução da intervenção cirúrgica. A utilização permitiu que o cirurgião sentasse e apoiasse os pés no chão, reduzindo a flexão dos joelhos e distribuindo as forças de apoio por diversos grupos musculares. Para a restrição de movimentação do cirurgião, outro acessório foi desenvolvido para apoiar o prepúcio do animal. Confeccionado em madeira, serve de suporte para mantê-lo distante do solo e próximo ao

Recebido em 20 de março de 2015

Aceito em 24 de fevereiro de 2016

E-mail: aloisiosv@hotmail.com 
cirurgião. Seu comprimento, largura e espessura estabeleceram boa relação com a altura do assento, proporcionando o mínimo de desconforto ao profissional. O terceiro dispositivo foi confeccionado para auxiliar na imobilização do animal e aumentar a segurança para o paciente e para a equipe de cirurgia. Um quarto acessório foi desenvolvido para proteger a região escapular e evitar a ocorrência de lesões de nervo radial, miopatias e traumas durante o derrubamento ou a permanência prolongada do animal em decúbito lateral. A escolha do formato, das dimensões e da maciez do dispositivo fundamentou-se principalmente no peso do animal. Tais dispositivos mostraram-se efetivos, pois reduziram o tempo de cirurgia, facilitaram a movimentação cervical e a lombar, além de proporcionarem um melhor apoio do cirurgião e, assim, reduzirem riscos de doenças osteomusculares.

Palavras-chave: bovino, cirurgia, enfermidades, pós-operatório

\section{INTRODUCTION}

According to Grandjean (1998), Ergonomics is an interdisciplinary science that comprises the physiology, labor psychology, anthropometry and the society at work. The practical objective of Ergonomics is the adaptation of the workplace, the instruments, the machines, the working hours and the environment to the requirements of man. Santos and Fialho (1995) describe that the Ergonomic Analysis of Work (EAW) studies a work situation in order to adapt it to man based on the analysis of technical, environmental and organizational conditions, seeking to reveal the differences between formal and actual work.

The adoption of ergonomic practices in various professions is an emergent need, since occupational diseases impact productivity and affect the social and economic well-being of workers and their families. About 68,157 million cases of occupational diseases are attributable to exposure to hazards or workload (Tavolaro et al., 2007).

In this context, some professions are considered stressful and often associated with harms to physical, mental and social health, among which dentistry, which is related to the Repetitive Strain Injury (RSI) and Work-Related Musculoskeletal Disorders (WMSD). In veterinary medicine, there is no central database of ergonomic injuries in Brazil. However, the scientific evidence indicates that the activities of veterinarians in various sectors expose workers to risk factors and hazards that may cause or worsen workrelated musculoskeletal disorders (Coster et al., 1987; Pereira et al., 2011).

Concerning the performance of the surgeons, it is observed that there was interest in the study of their relationship with work and with the proper environment in the 1930s research. This research culminated in the presentation by Berguer (1996) of Surgical Ergonomics that exposes guidelines to optimize the work of the surgeon, minimizing impacts, risks and hazards inherent to the causes or worsening of illnesses (Lawrence and Berry, 1939).

It is worth mentioning that the guidelines established by Berguer (1997) are exclusive for the activity of the professional in the surgical center and may be applied to Medicine and Veterinary Medicine, however, do not take into account the activity of the veterinarian performing surgical procedures in the field. Working conditions, in those situations, require efforts, postures and different movements by the professional, requiring attention and preparation related to the general guidelines in order to be adapted to the conditions present in the workplace.

The rule governing those issues, in Brazil, is the Regulatory Standard NR 32, which establishes the basic guidelines for the implementation of protective measures for the safety and health of workers in healthcare establishments, as well as of those who perform activities of health promotion and healthcare in general. Every risk should be examined considering the professional exposed and may be minimized through preventive measures and awareness training (Norma Regulamentadora NR 32 - Segurança e Saúde no Trabalho em Estabelecimentos de Assistência à Saúde).

In this sense, this work aimed to develop accessories to minimize impact and harm to the health of the veterinary surgeon that performs procedures in the field and to assess them regarding their efficiency, comparing procedures 
performed with and without the use of that equipment.

\section{MATERIAL AND METHODS}

The study was conducted based on the information collected in different rural properties in the state of Goiás, during the practical classes of Surgical Clinic in Large Animals, taught to Undergraduate and Graduate students and residents at the Veterinary Hospital of the Escola de Veterinária e Zootecnia of the Universidade Federal de Goiás (HV/EVZ/UFG). Some information was also obtained during the execution of outreach projects developed by the institution. Academic activities were approved by the Ethics Committee for Research of the Universidade Federal de Goiás, according to opinion 150/2010 and developed between 2010 and 2014. A surgical procedure lasting over 30 minutes and requiring movements, posture and strength on the part of the surgeon was selected. In this case, the query for professionals who would conduct the procedure proved to be suitable when electing the surgical treatment of acropostite-phimosis in bulls in the field.

Devices were then proposed and developed to provide improved comfort and safety to the surgeons. The first device was a stool to be used by the professional during the execution of the surgical intervention. The definitive measures of the device were established considering that the support should be total when the surgeon sat, without impairment for the conduction of the surgical maneuvers to be performed. The final aspect of the stool was the geometrical shape, a $27 \mathrm{~cm}$ - diameter circle with total area of 572 $\mathrm{sqcm}$. The stool is supported by four wooden columns. The dimensions of the columns were standardized at $20 \mathrm{~cm}$ length, being fixed on the lower portion of the stool, being connected to each other through a $13 \mathrm{~cm}$ length yoke (Figure 1 $\mathrm{A}$ and $\mathrm{B})$.

For the movement restriction of the surgeon, another accessory was developed to support the foreskin of the animal during the surgical intervention. This is a support block for the foreskin, made of wood, high enough to raise the foreskin of the animal and be a support for keeping it away from the ground and close to the surgeons. The shape and measurements of this device were also adjusted after the conduction of a number of surgical interventions. The parallelepiped-rectangle shape was the one that most adapted to the purpose proposed. Its length, width and thickness were respectively: $46 \mathrm{~cm}, 20$ $\mathrm{cm}$ and $8 \mathrm{~cm}$. Those measurements were sufficient to ensure a good relation with the stool height, providing minimal discomfort to the professional and enabling accurate maneuvers, without the risk of iatrogenic accidents (Figure 1 C and D).

The third device was made to assist in the immobilization of the animal in lateral decubitus and increase the safety for the patient and the surgical team. The shape of this accessory was designed in order for the metacarpal and metatarsal regions of the patient to be protected, thus avoiding possible ischemia while the animal remained immobilized. The objective was the development of a soft consistency accessory, easy to produce, with low cost and that minimized the possibility of blood vessel compression. Twisted plastic bags, with a $40 \mathrm{~kg}$ capacity, which previously stored bovine ration were used. The device was twisted until obtaining a rolling and flexible format (Figure $2 \mathrm{~A}$ and $\mathrm{B}$ ) in order to increase the resistance during pulling. The accessory was used to enlace the locomotion limbs of the animal, and tie, pull and fix the ropes in a single point during the immobilization. Thus, the direct tying of the ropes in the metacarpal and metatarsal regions of the patient to be submitted to surgery was avoided.

A fourth accessory was designed to protect the scapular region and avoid the occurrence of injuries in the radial nerve, myopathies and traumas during the rollover or prolonged stay of the animal in lateral decubitus (Figure $3 \mathrm{~A}$ and B). The choice of the shape, dimensions and softness of the device was mainly based on the weight of the animal. For animals with body weight between 500 and $1000 \mathrm{~kg}$, a $33-\mathrm{kg} / \mathrm{m}^{3}$ density foam was used, protected by resistant, waterproof and flexible canvas. The dimensions used for the production of the device were onemeter length and width and 10-cm thickness. 


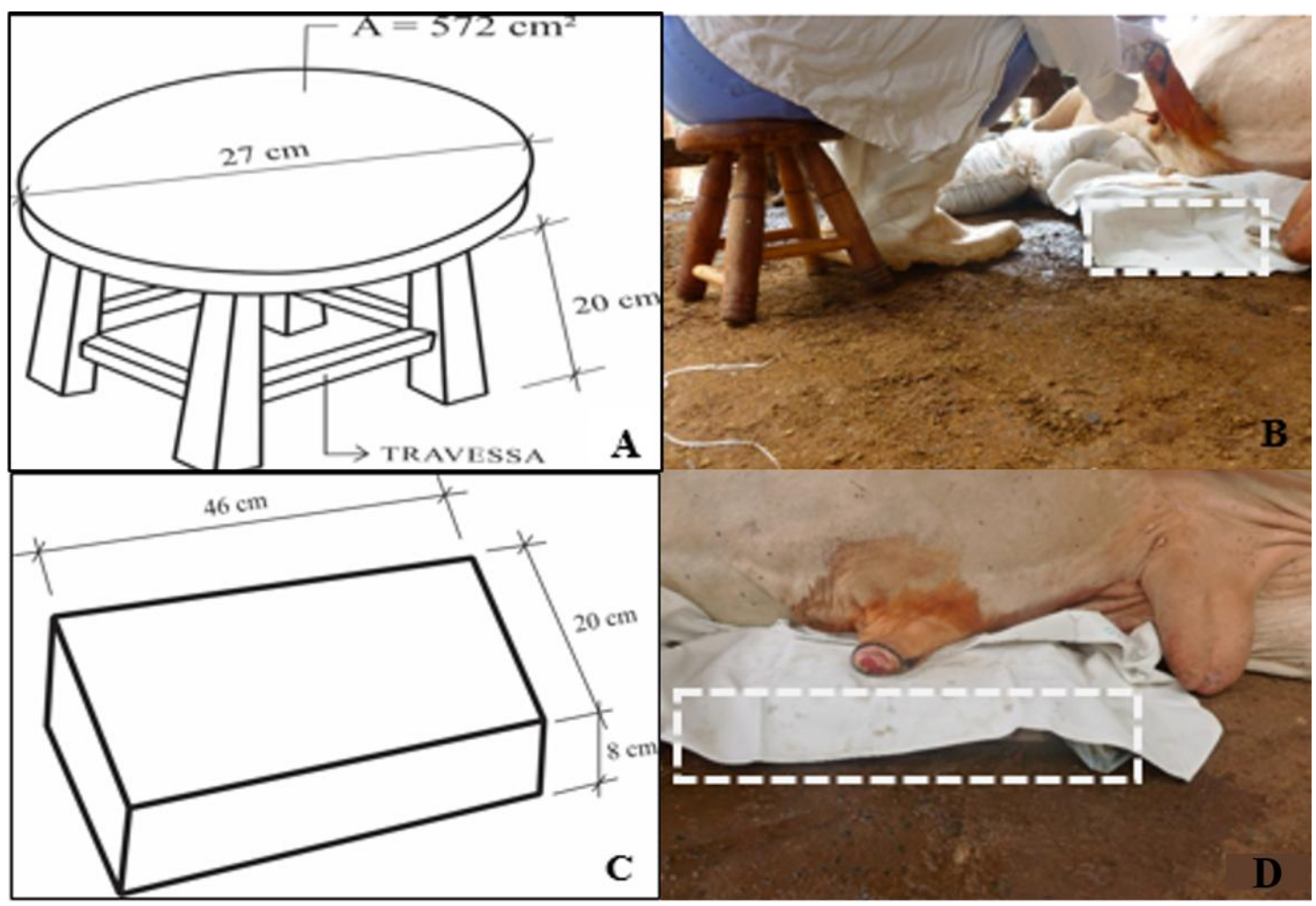

Figure 1. Devices designed to improve the posture of the veterinary surgeon during the surgical treatment of acropostite-phimosis in bulls in the field. In A, wooden stool with $572-\mathrm{sqcm}$ area supported by four feet, interconnected by wooden yokes. In B, the use of the stool by the surgeon, enabling the feet to rest on the ground and the arms on the knees. In $\mathrm{C}$, block made of wood to serve as a support of the bull foreskin. In D, support placed under the foreskin, reducing the distance between the surgeon and the surgical area
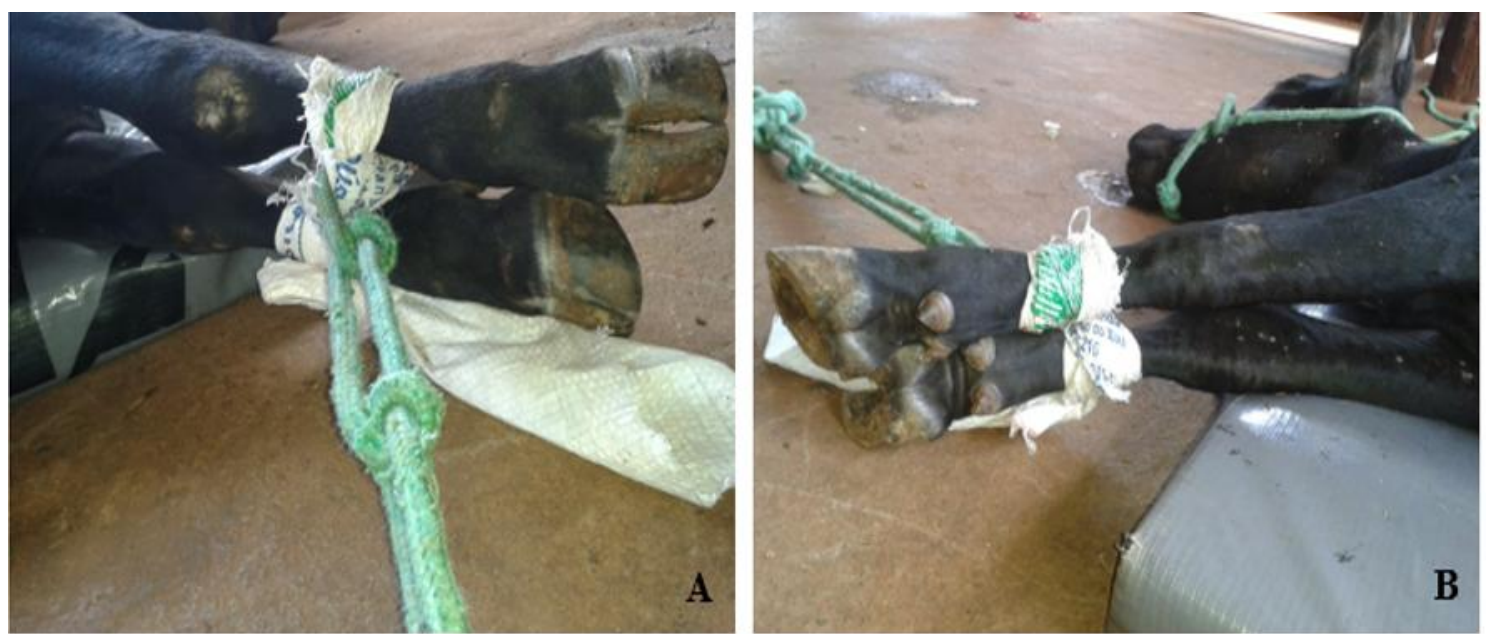

Figure 2. Immobilization device of the patient during the surgical treatment of acropostite-phimosis in bulls in the field. The device was made with twisted plastic bags and placed involving the metacarpal (A) and metatarsal (B) regions and attached to the ropes held in fixed supports. The immobilization of the limbs of the patient provides safety for the animal, the veterinary surgeon and assistants. 


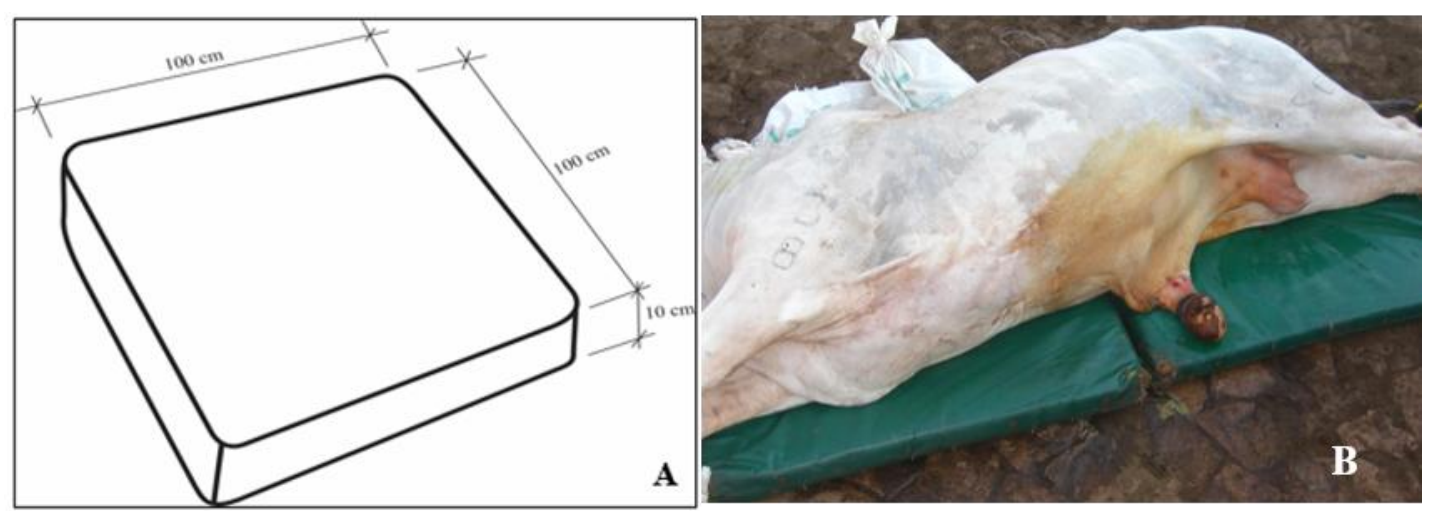

Figure 3. Device made of foam and coated with canvas, used for protecting the scapular region of bovines during the surgical treatment of acropostite-phimosis. (A) Dimensions of the protective pad. (B) Practical use of the accessory.

One hundred procedures conducted in bovines by three different surgeons were followed to check the efficiency of the wooden bench and the foreskin support, of which 50 were performed with the use of the accessories and 50 without their use. In all procedures, the duration of the surgery, the professional performing the procedure, posture and movement aspects of the surgeon, occurrence and time of arm resting, time of hand use for surgical maneuvers, cervical rotation, cervical flexion, lumbar rotation and flexion were recorded.

The immobilizers and protectors of the scapular region of the patients were used in all procedures, since they are necessary for the health and well-being of the animals. However, to check their effectiveness, the clinical postoperative parameters were verified, such as elevation claudication, flexion of the fetlock joint, difficulty in locomotion, signs of muscular discomfort and hemoglobinuria.

It was recommended that only one observer should conduct the recording during all procedures reported above in order to make the information mentioned above more accurate and reliable.

\section{RESULTS AND DISCUSSION}

The recording of the procedures revealed average time of 180 minutes when the surgeon did not use the accessories. On the other hand, when using the accessories, the average time was reduced to 75 minutes. In addition, there was a complete change of the posture of the surgeon, who, without the use of the accessories, remained in static postures that overloaded the joints.

Another important aspect was the reduction of cervical and lumbar rotation and flexion and the possibility of resting the arms on the knees, decreasing the impact on the joints of the lower and upper limbs, neck and torso. The data collected during the comparison of procedures with and without the use of accessories is compiled in Table 1.

Table 1. Posture and movement criteria observed during the activities of veterinary surgeons in acropostite-phimosis procedures in bulls, recorded between 2004 and 2014

\begin{tabular}{lcc} 
& \multicolumn{2}{c}{ Accessories } \\
\cline { 2 - 3 } & Without & With \\
\hline & $\mathrm{T}^{*}$ & $\mathrm{~T}^{*}$ \\
Surgical procedure & 180 & 75 \\
Positioned on the knees & 75 & 00 \\
Sitting on the floor & 75 & 00 \\
Arm resting & 00 & 47 \\
Use of hands for surgical & 75 & 47 \\
maneuvers & 20 & 05 \\
Cervical rotation & 70 & 30 \\
Cervical flexion & 50 & 15 \\
Lumbar rotation & 75 & 30 \\
Lumbar flexion &
\end{tabular}

$* \mathrm{~T}=$ Average time recorded in minutes.

The posture adopted by surgeons without the use of the stool was divided into three modes. In the first one, the surgeon sat on the ground with legs fully inflected, in the second one, the surgeon remained resting on the knees and, in the third 
one, the professional was resting only on the feet with legs inflected (Figure 4A, 4B and 4C). All postures remained static until the end of the procedure that, associated with the repetitiveness of movements, the use of force and accuracy, may favor the occurrence of Work-related Musculoskeletal Disorders (WMSDs) and, consequently, harm the overall health of those professionals. Lusvarghi (1999) and Peres et al. (2005) noted the occupational activities of dental professionals and the greater predisposition to develop back problems such as the root compression syndrome, osteoarthritis and joint damage, in addition to bursitis caused by shoulder abduction movements. The authors point out that the main causes are the inappropriate and static postures, which contribute to an increased frequency of arterial and musculoskeletal diseases.

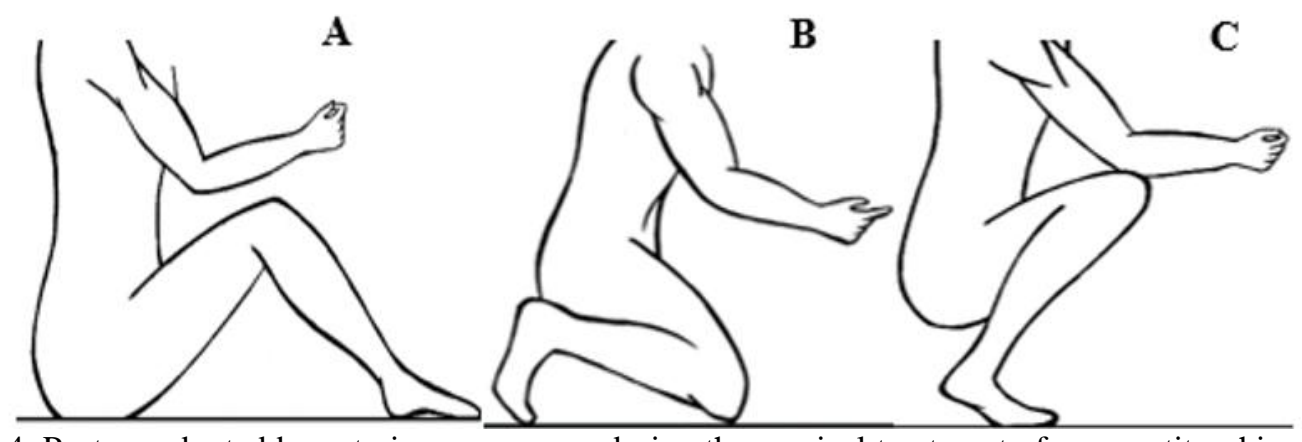

Figure 4. Posture adopted by veterinary surgeons during the surgical treatment of acropostite-phimosis in bulls in the field. In A, the professional sat on the ground, keeping the legs fully inflected. In B, the professional leaned on the knees. In $\mathrm{C}$, the professional stood on the feet. In the three positions, the joints and muscles of lower and upper limbs, back and neck are overloaded.

The use of the wooden device enabled the surgeon to sit down and rest the feet on the ground, reducing the bending of the knees and distributing the support forces through several muscle groups. In addition, there was great reduction of cervical and lumbar flexion and rotation. This new posture reduced the overload in the back muscles, intervertebral ligaments, intervertebral discs, in addition to shoulder, arm and forearm muscles (Fig. 5) (Peres et al., 2005).

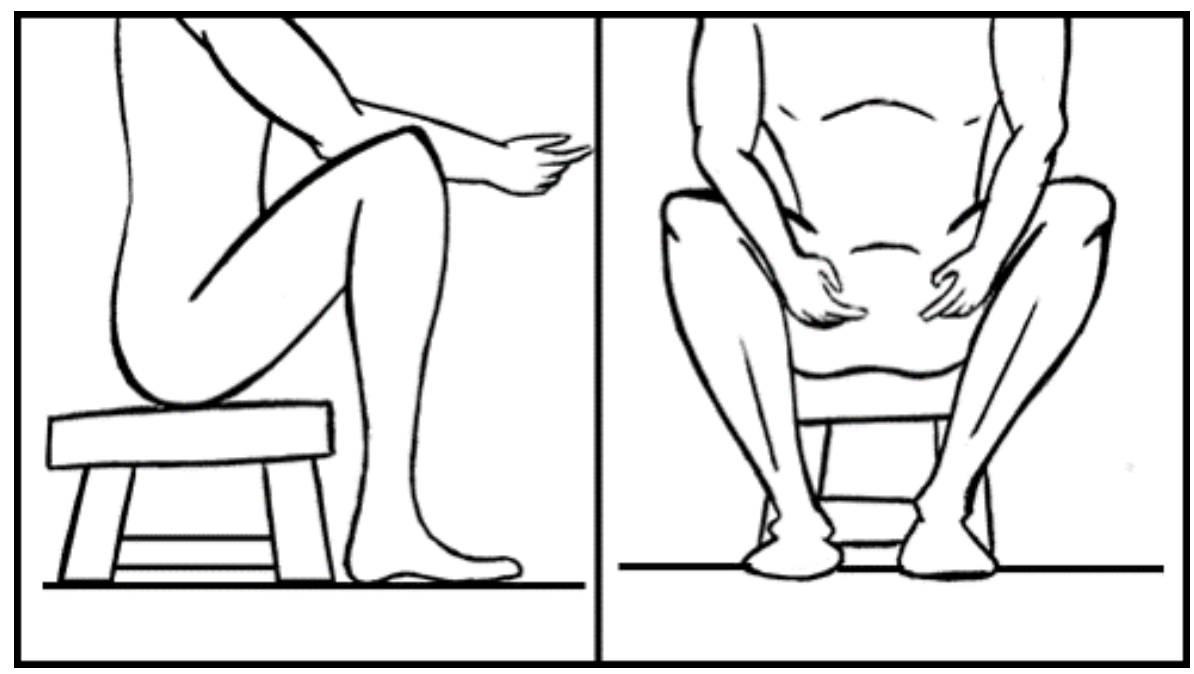

Figure 5. Scheme of the wooden stool serving as a seat for the surgeon. It can be noted that the professional may rest the feet on the ground, move the lower limbs freely and rest the arms on the knees. 
The devices made with plastic bags provided safety during the immobilization of the animals in lateral decubitus. The resistance and consistency were benefits provided by the protective accessory of the metacarpal and metatarsal regions, because, besides not rupturing when pulled, its softness provided comfort to the animal and minimized the compression of blood vessels in those two anatomical regions, a concern also mentioned by Silva et al. (2012).

The padded accessory avoided the compression of the radial nerve and myopathies in bulls with body weight up to $1000 \mathrm{~kg}$. For heavier animals, it was necessary to place two overlapping devices in order for the local protection to be complete. The foam coating with waterproof canvas proved to be important for the conservation of the material, being easy to clean, preventing liquid substances such as saline, water, antiseptic products and body fluids to damage the device. The padded accessory used for protecting the scapular region was effective, and clinical signs such as elevation lameness, flexion of the fetlock joint, difficulty in locomotion, muscular discomfort and hemoglobinuria were not observed. Such signs are frequently identified when there is nervous impairment and myopathies in bovines. Similar information has also been mentioned by Rabelo et al. (2006), and Rabelo and Silva (2011) in surgeries for the treatment of acropostitephimosis in bulls.

Those findings allow the statement that the dimensions of the pad and the density of the foam used were appropriate for the protection of the scapular region of bulls submitted to the surgical treatment of acropostite-phimosis. In analogy to what occurs in dental offices, where the dental chair should provide comfort to the patient, not demanding discomfort from the dentist and the assistant, the comfort equipment for the patients of the veterinary surgeon should act in the same way. In this case, Marquart (1980) mentions that the chair should provide a relaxed and firm posture without discomfort for the patient, as well as provide an ergonomic and technically correct work for the dental team.

According to Figlioli (1988), dental chairs should provide support for all regions of the patient's body, also enabling the adjustment of the height and the position of headrest, which should be articulated, to enable back and forth and left and right movement, making vision easier, and enabling more comfortable positions to work in the mouth of the patient. Another aspect, considered one of the most important for the comfort of the team, is the free space under the backrest of the seat, enabling the wide movement of the team's legs.

Therefore, it was verified that the comfort provided to the patients of the veterinary surgeon have reduced their resistance and movement during the procedure, increasing the safety of the surgery team and enabling, along with the other accessories, the movement of the arms and legs of the surgeon, similarly to what happens at the work equipment interface of dentists.

\section{CONCLUSIONS}

The development and evaluation of the stool for the surgeon, support block for the foreskin, immobilizers for the metacarpal and metatarsal regions and pad for protecting the scapular region proved to be effective, reducing the time of the acropostite-phimosis surgery in bulls submitted to surgery in the field and the cervical and lumbar movement of the surgeon, providing better support to the professional and reducing the overload on muscles and joints and the risks of musculoskeletal diseases.

\section{REFERENCES}

BERGUER, R.; The application of ergonomics to general surgeons working environment. Environ. Health, v.12, p.99-106, 1997.

COSTER, E.A.; CARSTENS, I.L.; HARIS, A.M.P. Patterns of stress among dentists. J. Dent. Assoc. S. Afr., v.42, p.389-394, 1987.

FIGLIOLI, M.D. Posições de trabalho do cirurgião-dentista e auxiliar odontológica na execução de preparos de cavitários, usando sucção de alta potência e dique de borracha previamente colocado. 1988. [n.f.]. Tese (Doutorado em Ciências Odontológicas) Faculdade de Odontologia, Universidade Estadual Paulista, Araraquara, SP.

GRANDJEAN, E. Manual de ergonomia. Porto Alegre: Artes Médicas, 1998. 338p. 
LAWRENCE, J.A.; BERRY, C.H. Arrangement of operating room. Am. J. Surg., v.43, p.669-674, 1939.

LUSVARGHI, L. Cuide-se bem: profissional saudável não tem idade. Rev. Assoc. Paul. Cir. Dent., v.53, p.89-100, 1999.

MARQUART, E. Odontologia ergonômica a 4 mãos. Rio de Janeiro: Quintessência do Brasil, 1980. $125 \mathrm{p}$

PEREIRA, A.S.; FONSECA, M.F.; AIZAWA, L.H. et al. Estudo da prevalência de doenças ocupacionais em cirurgiões-dentistas de São José dos Campos. Odonto, v.19, p.7-14, 2011.

PERES, S.A.; PASCHOARELLI, L.C.; SILVA, R.H.A.; KUSHIMA, F.A interface tecnológica nas atividades ocupacionais dos cirurgiõesdentistas: uma abordagem do design ergonômico. Rev. Odontol. Araçatuba, v.26, p.44-48, 2005.
RABELO, R.E.; SILVA, L.A.F; VIU, M.A.O. et al. Acrobustite bovina: revisão de literatura. Rev. CFMV, v.12, p.30-37, 2006.

RABELO, R.E.; SILVA, O.C. Aspectos morfofuncionais, clínicos e cirúrgicos do pênis, prepúcio e testículos de touros. Goiânia: Kelps, 2011.212p.

SANTOS, N.; FRANCISCO FIALHO, A.P. Manual de análise ergonômica do trabalho. Curitiba: Gênesis, 1995. [s.p.].

SILVA, L.A.F.; EURIDES, D.; RODRIGUES, D.F.; SOUZA, L.A. et al. Contenção física de animais domésticos, selvagens e de laboratório. Goiânia: Kelps, 2012. 294p.

TAVOLARO, P.; PEREIRA, I.M.T.B.; PELICIONI, M.C.F.; OLIVEIRA, C.A.F. Empowerment como forma de prevenção de problemas de saúde em trabalhadores de abatedouros. Rev. Saúde Pública, v.41, p.307312, 2007. 